\title{
Second Language Anxiety and Distance Language Learning
}

\author{
François Pichette
}

\author{
Université du Québec à Montréal
}

\begin{abstract}
This study compared anxiety profiles of classroom and distance language learners, and compared anxiety levels between first-semester and more experienced students in both learning environments. Participants were 186 French-speaking learners of English or Spanish, who were tested in Canada in 2006. They were tested for general foreign language anxiety, for second language (L2) reading anxiety, and for L2 writing anxiety. Results show no significant differences in anxiety profiles between classroom and distance learners, and higher anxiety among first-semester distance learners. However, in the case of classroom learners, our data contradict earlier research by indicating similar levels of anxiety between first-semester and more experienced students. Results are discussed in light of the changing profile of distance learners and the school system where participants were tested.
\end{abstract}

Key words: anxiety, distance learning, second language acquisition

Language: French, relevant to all languages

\section{Introduction}

\section{Anxiety and Language Learning}

Some students display less self-confidence and are more prone to anxiety than others: They tend to become uncomfortable in the presence of peers in the classroom or when faced with academic tasks; they are worried about making mistakes and losing face; and they fear criticism, negative evaluation, judgmental remarks, and so on. The pressure is even greater when it comes to second language (L2) learning, where current approaches stress the importance of oral interaction between students, which is probably the most important source of anxiety for learners (Ellis, 1994; Frantzen \& Magnan, 2005; Koch \& Terrell, 1991; Matsuda \& Gobel, 2004; Young, 1991).

A large number of studies have demonstrated negative relationships between anxiety and academic performance in foreign language learning (e.g., P. Bailey, Onwuegbuzie, \& Daley, 2000; Chen \& Chang, 2004; Horwitz, 2001; MacIntyre \& Gardner, 1991; Phillips, 1992; Sparks \& Ganschow, 2007; Young, 1999a). ${ }^{1}$ These negative correlations have lent support to anxiety-reducing teaching methods, such as the Natural Approach (Krashen \& Terrell, 1983), Community Language Learning (Curran, 1976; see Ariza, 2002), and Suggestopedia (Lozanov, 1978;

François Pichette (PhD, Université de Montréal) is Professor of linguistics at Université du Québec à Montréal (Téluq), Montreal, Canada. 
see Bancroft, 1976). Several theoreticians in second language acquisition (SLA) address anxiety as an important variable in their theories and models, such as Gardner's (1982) Socio-educational model, Krashen's (1982) Monitor model, and Woodrow's (2006a) Adaptive language model.

General foreign language anxiety is defined here as anxiety related to learning a foreign language and to engaging in L2 learning activities. It is said to involve emotional arousal and negative self-related cognition that would interfere with effective language learning (MacIntyre, 1995). Foreign language anxiety has been the focus of increased research in the last two decades, and of the four traditional language skills (speaking, writing, reading, and listening) involved in such studies, the research has traditionally concentrated on speaking anxiety as its main component (Horwitz, 2001; Lucas, 1984; Phillips, 1992; Price, 1991; Woodrow, 2006b). Researchers have also begun to investigate more specific types of anxiety in relation to foreign language learning, and pertaining to different skill areas: foreign language writing anxiety (Cheng, Horwitz, \& Schallert, 1999; Daly \& Miller, 1975), foreign language reading anxiety (Saito, Garza, \& Horwitz, 1999), and foreign language listening comprehension anxiety (Kim, 2000; Vogely, 1998).

\section{Anxiety and Distance Learning}

Students have provided several reasons for choosing distance learning, the most common being the place where they live, their work schedule, the costs, life roles, commuting difficulties, disability, and individual variables. This study focused on one such variable: foreign language anxiety. The research assumed that students' tendency to be anxious when faced with language learning tasks impacts their learning processes and academic performance.

Since general foreign language anxiety makes students reluctant to interact with their peers in the classroom, one could expect that some students resort to distance learning for that particular reason and to seek security in anonymity, more than other factors related to their location or their work schedule. In fact, language professors and tutors ${ }^{2}$ working in distance learning often report considerable amounts of anxiety and lack of self-confidence reflected in students' concerns about the course and its components (B. Chabot, personal communication, June 12, 2005). Burge, Howard, and Ironside (1991) asked 447 students from four Canadian universities what kind of help they were expecting from their tutor, and $20.2 \%$ of their respondents mentioned the need to sustain and develop their self-confidence. In another study with distance students, Gagné, Bégin, Laferrière, Léveillé, and Provencher (2001) also showed that $18 \%$ of their students expected motivational support (encouragement and comments that enhance students' motivation) to be the most important role of their tutors and that their satisfaction was influenced by that factor at a level of $78 \%$. These figures were higher than for other factors, e.g., tutors' knowledge of course content.

One can thus explain students' choice of distance learning in part by their anxiety related to foreign language oral interaction, which, as mentioned earlier, is the principal skill addressed by general foreign language anxiety tests. Given these considerations, it would be legitimate to hypothesize that general foreign language anxiety should be particularly present in distance learning among L2 students, since language courses are by their nature disciplines where students are expected to interact orally with their peers.

Numerous researchers have investigated aspects of the distance student's individual variables, e.g., motivation, learning style, introversion, autonomy, flexibility, tolerance for ambiguity, locus of control, or self-directedness. ${ }^{3}$ However, surprisingly, no researcher has apparently investigated the factor of anxiety in distance learning. ${ }^{4}$ To date, no empirical data exist as to whether there is a difference in anxiety profiles between classroom students and distance learning students, where the latter would present higher scores 
on a standardized measure of general foreign language anxiety.

\section{The New Face of Distance Learning}

Despite the aforementioned assumptions about differences in anxiety profiles, recent factors raise doubts about choosing distance courses for anxiety reasons. The first factor is a change in the profile of distance learners that has taken place over the last decade. Even though, in comparison with classroom learners, distance learners still tend to be older, have more family responsibilities, live typically farther away from their place of studies, and more often work in addition to studying (Dutton, Dutton, \& Perry, 2002), their socio-demographic profile resembles more and more that of classroom learners. This merger of profiles could play a role in decreasing or blotting out differences in anxiety profiles between the two student groups. In Quebec, where this study took place, the number of people taking distance courses went from 61,471 to 110,378 from 1995 to 2005 (Pilon, 2006, p. 9), which represents an $80 \%$ increase over 10 years, while the general student population increased by only $7.5 \%$ over the same period, going from 237,906 to 255,663 (Crépuq, 2005, n.p.). At the same time, the percentage of Téluq ${ }^{5}$ students who were younger than 30 went from 39.5 to $45.3 \%$ over the same time period (Teluq, 2004, n.p). The dichotomy between classroom and distance students also tends to disappear: $35 \%$ of the more than 20,000 distance students at Téluq also take classroom courses at other institutions (Téluq, 2004, n.p.).

A second mitigating factor lies in the nature of distance courses. In 2006, the typical language distance course was online, with chat rooms, and many students were equipped with software for chatting with voice and video. Therefore, there is much more oral interaction than in the days where students would receive course manuals by mail and oral interaction was limited to scarce conversations over the phone with their tutors. In a certain way, most students probably know that today's distance courses involve these modern communication features and possibilities, and they are aware that oral interaction is even more likely to take place.

\section{Anxiety and Language Learning Experience}

Anxiety has been shown for many years to be a key factor in language learning, especially for first-semester students, since courserelated anxiety has been shown to be higher for beginners than for experienced language learners (Frantzen \& Magnan, 2005; Gardner \& MacIntyre, 1993; Liu, 2006) and more influential on academic performance than in the case of more experienced students (Saito \& Samimy, 1996; Samimy \& Tabuse, 1992). P. Bailey and his colleagues (2000) have shown that more languageanxious university students tend to have taken few or no high school foreign language courses. As students gain language learning experience and increased language competence, their language anxiety tends to go down. For example, Gardner, Smythe, and Clément (1979) showed a decrease in anxiety toward speaking French after only 5 or 6 weeks of an intensive course, due to the positive impact of proficiency on selfconfidence (Gardner, Tremblay, \& Masgoret, 1997). Other researchers have observed similar decreases in anxiety after a semester of intensive language learning (Baker $\&$ MacIntyre, 2000; Tanaka \& Ellis, 2003). ${ }^{6}$

\section{Research Questions}

The research questions addressed by the present study are the following:

1. Do classroom and distance language learners show different anxiety profiles?

2. Is anxiety higher for first-semester students in both settings?

The mitigating factors mentioned earlier, i.e., distance learning becoming mainstream and distance courses being increasingly 
interactive, suggest that students may not necessarily choose distance courses based on their expectations of lower oral interaction. Consequently, the answer to the first research question, which would have probably been positive a few years ago, cannot be easily predicted now. Regarding Question 2, higher anxiety for first-semester students would indicate a decrease in anxiety with increased language learning experience, as suggested by previous research. In the absence of indications to the contrary, this research expected distance learners to reflect the pattern observed among classroom learners.

The researchers expect the answers to our research questions to provide distance learning teachers and tutors with more information on their students' general personality profiles so that they can adapt their interventions accordingly. More anxious students will need different amounts and types of interventions than confident students. Examples of anxious students' needs related to course design and group dynamics include more extensive written material at their disposal, focus on processes rather than on final results of activities, help from a paired note taker (Hamel, 2006), more class time spent preparing for tests and availability of older test versions (Davis, 1993), more sentence repetitions (MacIntyre \& Gardner, 1994), slower pace (Frantzen \& Magnan, 2005), use of portfolios (Abu-Rabia, 2004), use of less material at a time (VanPatten $\&$ Glass, 1999), humorous content (Berk, 2000), extra time for asking questions (Qin, 2003), and meaningful, lively, and interesting material (Abu-Rabia, 1999).

\section{Materials}

\section{Measuring General Foreign}

\section{Language Anxiety}

The researchers measured general foreign language anxiety using the foreign language classroom anxiety scale (FLCAS), developed by Horwitz, Horwitz, and Cope (1986), which is the most widely used scale for assessing general foreign language anxiety. This instrument consists of 33 items, about 20 of which focus on listening and speaking skills, and the remaining items are related to general language anxiety with no items related to writing or reading (see Appendix A). Consequently, the main focus of the FLCAS is on anxiety related to oral communication, and scores on this scale are identified in the tables as "general/oral" anxiety to remind the reader of the scale's main focus. The FLCAS adopts a 5-point Likert scale ranging from "strongly agree" to "strongly disagree." Reliability levels in the order of .80 or above have been reported for the FLCAS (Aida, 1994: $r=.80$; Cheng et al., 1999: $r=.95$; Elkhafaifi, 2005: $r=.94$; Horwitz et al., 1986: $r=.83$; Saito et al., 1999: $r=.94$ ).

Originally designed for measuring anxiety related to English learning, the FLCAS has been shown to yield scores that are consistent across languages (Rodríguez \& Abreu, 2003; Saito et al., 1999). Consequently, the researchers used the modified FLCAS here for learners of Spanish, as did Saito and her colleagues (1999).

Given that the main focus of the FLCAS is on oral communication, this study also needed to use measures of written communication - reading and writing - in order to obtain more complete information on the students' anxiety profile. In fact, reading and writing have been identified among the major anxiety-provoking factors other than oral interaction. This has led some researchers to use the FLCAS in combination with measures of reading and writing anxiety. The two most famous measures are the Daly-Miller Writing Apprehension Test (WAT; Daly \& Miller, 1975), and the Foreign Language Reading Anxiety Scale (FLRAS; Saito et al., 1999). This study used both instruments, and they are included in Appendix A.

\section{Measuring Foreign Language Reading} Anxiety: The FLRAS

The FLRAS is an instrument that was made public in 1999 by Saito et al. and inspired by the FLCAS. It consists of 20 items, also in the form of 5-point Likert scales. Students must report their anxiety over aspects of reading in 
a foreign language and the difficulty they perceive with respect to L2 reading. The creators of the FLRAS report an internal consistency coefficient of $.86(n=383)$. In this study, Questions 10, 11, 15, and 16 were eliminated, since they are only relevant in cases where the participant is confronted with a new writing system. ${ }^{7}$ Questions 15 and 16 had also been eliminated by Matsuda and Gobel (2004) from their factor analysis based on their low factor loadings and low commonalities.

\section{Measuring Foreign Language Writing} Anxiety: The WAT

The test used for measuring foreign language writing anxiety is the WAT (Daly $\&$ Miller, 1975). A good case for its use in the place of other similar tests was made by Wiltse (2000), who found a Cronbach's alpha coefficient for reliability of .95 $(n=188)$ :

The Daly-Miller Writing Apprehension Test (1975) has undergone a long program of validation and reliability testing, and its reliability has been measured with Cronbach alpha coefficients ranging from 89 (Daly, 1979) to .94 (Daly \& Miller, 1975). The WAT has been widely used by its creators and other researchers, and has been found to be highly valid. Factor analysis showed positive and above .60 loadings between each factor and at least two items. (Wiltse, 2000, p. 68)

Since the WAT, a 26-item questionnaire, is designed for writing in general, and not specifically for foreign language writing, the researchers added the words "English/ Spanish" or "in English/in Spanish" to the items, an adaptation method that Cheng et al. (1999) also used.

\section{Advantages of an Online \\ Questionnaire}

The researchers accessed all instruments and materials involved in this study on a Web site designed for this study. Participants received a combination of all 75 questions from the three anxiety tests. An online survey program allowed us to display questions in random order with a different sequence for each participant. This design helped prevent fatigue or haste effects in answering the last questions, or test-taking anxiety effects on the first questions, a possibility that was not addressed in previous related studies. The choice of an online questionnaire not only made it easier to reach distance students, but it also prevented additional caveats related to paper testing:

1. it ensured that no answers were left blank, by notifying the participant automatically; and

2. it prevented participants from crossing out more than one answer per item out of distraction, thus ensuring that all items could be included in the analyses.

\section{Other Measures}

In addition, an online background questionnaire in French (see Appendix B) was used to gather socio-demographic information such as name, gender, age, course level, and college affiliation.

\section{Procedure}

\section{Participants}

Participants in this study were adult Frenchspeaking students of English or Spanish as a second language, taking classes either in a classroom or in distance learning, in universities located in Québec, Canada. Technology used in the participants' distance courses varied from one course to the next, as is the case with classroom participants, and they included audiovisual components on CDs and the Internet, phone conversations, and so on.

Originally, a total of 205 language students logged in to our study Web site, out of which 186 completed the questionnaires. Table 1 presents detailed information about each participant's profile. No participant was involved in both types of learning at the time of testing. The background questionnaire 


\section{TABLE 1}

Overview of Participants' Profiles

\begin{tabular}{|c|c|c|c|c|}
\hline & & $\begin{array}{c}\text { Classroom } \\
\text { learners }\end{array}$ & $\begin{array}{l}\text { Distance } \\
\text { learners }\end{array}$ & Total \\
\hline \multirow{4}{*}{$\begin{array}{l}\text { Learners } \\
\text { of } \\
\text { English }\end{array}$} & $N$ & 70 & 59 & 129 \\
\hline & Age & 24.0 [18-53] & 39.0 [23-63] & 30.7 [18-63] \\
\hline & Gender & $\mathrm{F}=50, \mathrm{M}=20$ & $\mathrm{~F}=42, \mathrm{M}=17$ & $\mathrm{~F}=92, \mathrm{M}=37$ \\
\hline & Level $^{\mathrm{a}}$ & $\begin{array}{l}B=10, I=28 \\
A=32\end{array}$ & $\begin{array}{l}B=7, I=33 \\
A=19\end{array}$ & $\begin{array}{l}B=17, I=61, \\
A=51\end{array}$ \\
\hline \multirow{4}{*}{$\begin{array}{l}\text { Learners } \\
\text { of } \\
\text { Spanish }\end{array}$} & $N$ & 37 & 20 & 57 \\
\hline & Age & 24.3 [19-49] & 32.7 [21-49] & 27.2 [19-49] \\
\hline & Gender & $\mathrm{F}=26, \mathrm{M}=11$ & $\mathrm{~F}=13, \mathrm{M}=7$ & $\mathrm{~F}=39, \mathrm{M}=18$ \\
\hline & Level & $\begin{array}{l}B=32, I=5 \\
A=0\end{array}$ & $\begin{array}{l}B=14, I=6 \\
A=0\end{array}$ & $\begin{array}{l}B=46, I=11, \\
A=0\end{array}$ \\
\hline \multirow[t]{4}{*}{ Total } & $N$ & 107 & 79 & 186 \\
\hline & Age & 24.1 [18-53] & 37.4 [21-63] & 29.6 [18-63] \\
\hline & Gender & $\mathrm{F}=76, \mathrm{M}=31$ & $\mathrm{~F}=55, \mathrm{M}=24$ & $\begin{array}{l}\mathrm{F}=131 \\
\mathrm{M}=55\end{array}$ \\
\hline & Level & $\begin{array}{l}B=42, I=33 \\
A=32\end{array}$ & $\begin{array}{l}B=21, I=39 \\
A=19\end{array}$ & $\begin{array}{l}B=63, I=72, \\
A=51\end{array}$ \\
\hline
\end{tabular}

${ }^{\mathrm{a}} \mathrm{B}=$ beginner, $\mathrm{I}=$ intermediate, $\mathrm{A}=$ advanced.

indicated that more than $98 \%$ of all participants had never taken a distance course before the semester when they were tested; only one of the 107 classroom students and only two of the 79 distance learners had already done so. Money was awarded posthoc as participation prizes in the form of a lottery.

\section{Testing Time}

There was no time limit for filling out the questionnaire and answering the total of 75 questions comprising the three tests, but average total testing time was about 25 minutes.

\section{Scoring}

All instruments being 5-point Likert scales, we awarded a number of points from 1 to 5 for each answer. For all negatively worded statements, e.g., "It embarrasses me to volunteer answers in my English class," we awarded points ranging from 1 (strongly disagree) to 5 (strongly agree). We reverse scored all the positively worded statements, so that in all cases high scores on an item represented high levels of anxiety. We calculated the means displayed in the tables based on the total scores for each individual.

\section{Results: Learners of Spanish vs. Learners of English}

To verify that there is no statistical difference between learners of English and Spanish, we performed a $t$ test for each measure of anxiety. Table 2 shows mean scores for all three components. In this table as well as in the following ones, scores are in the form of means followed by their standard deviation in parentheses. 


\section{TABLE 2}

Anxiety Measures: Learners of Spanish vs. Learners of English

\begin{tabular}{|lccc|}
\hline & $\begin{array}{c}\text { Spanish } \\
(N=57)\end{array}$ & $\begin{array}{c}\text { English } \\
(N=129)\end{array}$ & $t$ test \\
\hline $\begin{array}{l}\text { General/oral } \\
\text { anxiety }\end{array}$ & $54.32(14.07)$ & $57.20(14.95)$ & $1.26(p=.10)$ \\
\hline Reading anxiety & $46.40(12.32)$ & $48.08(13.88)$ & $0.82(p=.21)$ \\
\hline Writing anxiety & $50.05(14.56)$ & $52,74(14.76)$ & $1.15(p=.13)$ \\
\hline
\end{tabular}

$T$ tests show no significant difference between the two groups of learners, given that all $p$ values are above an alpha level set at .05. This absence of statistical difference allows us to combine the two subgroups for further analyses in light of our research questions.

Question 1: Do classroom and distance language learners show different anxiety profiles?

$T$ tests show low $t$ values accompanied by high $p$ values, which indicate the absence of statistical differences between classroom and distance learners (see Table 3). These results suggest that factors related to the changing profile of distance learners and distance courses do seem to stamp out the differences that could be expected between the two groups. Based on these data, the answer to our first research question is negative: There is no difference in anxiety profiles between classroom and distance learners.

In addition, in each setting, all anxiety scores correlate positively at $p \leq .001$, suggesting that people who tend to be anxious about an aspect of language interaction also tend to be anxious about the other aspects.

Question 2: Is anxiety higher for firstsemester students in both settings?

We conducted the same analyses here as for our first research question, this time comparing students taking their first language course at the university with those who are at their second semester or beyond (see Table 4). ${ }^{8}$

This time again, $t$ tests yield no significant difference between groups, thereby providing a negative answer to our second research question.

\section{TABLE 3}

Anxiety Measures: Classroom vs. Distance Learners

\begin{tabular}{|lccc|}
\hline & $\begin{array}{c}\text { Classroom learners } \\
(N=107)\end{array}$ & $\begin{array}{c}\text { Distance learners } \\
(N=79)\end{array}$ & $t$ test \\
\hline $\begin{array}{l}\text { General/oral } \\
\text { anxiety }\end{array}$ & $56.33(15.46)$ & $56.29(13.72)$ & $0.02(p=.49)$ \\
\hline $\begin{array}{l}\text { Reading } \\
\text { anxiety }\end{array}$ & $47.84(13.29)$ & $47.20(13.65)$ & $0.32(p=.37)$ \\
\hline $\begin{array}{l}\text { Writing } \\
\text { anxiety }\end{array}$ & $53.13(14.74)$ & $50.27(14.61)$ & $1.31(p=.09)$ \\
\hline
\end{tabular}




\section{TABLE 4}

Anxiety Measures: First-Semester vs. More Experienced Students

\begin{tabular}{|lccc|}
\hline & $\begin{array}{c}\text { First semester } \\
(\mathrm{N}=102)\end{array}$ & $\begin{array}{c}\text { Two semesters and } \\
\text { up }(\mathrm{N}=84)\end{array}$ & t test \\
\hline $\begin{array}{l}\text { General/oral } \\
\text { anxiety }\end{array}$ & $57.11(14.34)$ & $55.35(15.18)$ & $0.81(p=.21)$ \\
\hline $\begin{array}{l}\text { Reading } \\
\text { anxiety }\end{array}$ & $48.82(12.69)$ & $46.04(14.16)$ & $1.40(p=.08)$ \\
\hline $\begin{array}{l}\text { Writing } \\
\text { anxiety }\end{array}$ & $53.46(13.25)$ & $50.04(16.20)$ & $1.56(p=.06)$ \\
\hline
\end{tabular}

Regardless of the absence of statistical difference, Table 4 shows a tendency for more experienced students to be less anxious than their first-semester counterparts, especially when it comes to non-oral aspects of language learning (reading and writing): all their anxiety measures are lower, with reading and writing anxiety having $p$ values near the .05 threshold with higher $t$ values. The second research question required that the same $t$ tests be conducted separately for distance and classroom learners (see Table 5).

This analysis yielded unexpected results. On the one hand, in the case of class room learners, there seems to be absolutely no difference in anxiety between first-semester students and their more experienced peers. These results contradict those from prior studies (e.g., Saito \& Samimy, 1996; Samimy \& Tabuse, 1992). On the other hand, distance learners follow the expected pattern, with more experienced learners showing less anxiety, except in the case of writing anxiety, for which firstsemester learners are likely to show little anxiety, for reasons that are exposed in the discussion hereafter.

\section{Discussion}

Regarding our first research question, the absence of a difference in anxiety profiles between classroom and distance students suggests that anxiety and expectations of fewer or no oral interactions should be rejected as a probable major reason for

\section{TABLE 5}

Anxiety Measures: First-Semester vs. More Experienced Students; $t$ Test Results by Subgroups

\begin{tabular}{|lcc|}
\hline & $\begin{array}{c}\text { Classroom learners } \\
(N=107)\end{array}$ & $\begin{array}{c}\text { Distance learners } \\
(N=79)\end{array}$ \\
\hline $\begin{array}{l}\text { General/oral } \\
\text { anxiety }\end{array}$ & $-0.32(p=.38)$ & $1.77(p=.04)$ \\
\hline Reading anxiety & $0.26(p=.40)$ & $1.77(p=.04)$ \\
\hline Writing anxiety & $0.48(p=.31)$ & $1.53(p=.65)$ \\
\hline
\end{tabular}


today's students to engage in distance learning.

Results in Tables 4 and 5 suggest a negative answer to Question 2, but they also raise the question of why first-semester language students in Québec are not more anxious than their more experienced fellow students, with $p$ values nearing significance although without reaching it. One likely explanation is that in this case, in Québec, unlike in the United States, the research compares two groups of relatively experienced language students. After mandatory L2 courses at school from the age of 9, in addition to possible language courses in cegeps, ${ }^{9}$ university students in Québec are used to taking language courses, be they in their first or fourth semester at the university. A hypothesis that needs further investigation is that anxiety decline would become less marked among more experienced language learners, even though extended experience does not imply lower anxiety, as Casado and Dereshiwsky (2004) concluded based on data from school systems comparable to those discussed here:

The results also suggest that the lack of a nationwide compulsory foreign language program in U.S. grade schools may not necessarily imply higher levels of anxiety for first-semester university students than those experienced by comparable students in Spain, where the second language is imparted universally since age eight. (p. 35)

In addition, despite the absence of significant differences between subgroups in our tables, some tendencies appear that call for further exploration. For example, learners of Spanish reflect a tendency to be less anxious than learners of English (see Table 2), with all their anxiety measures being lower than those obtained by learners of English. Data from similar studies with different, larger groups could achieve significance for several reasons. The first reason is prior experience in L2: All our Spanishlearning participants had taken courses of
English as a second language (ESL) — with the exception of the one native speaker of English who had taken courses of French - and $18 \%$ of them had also taken at least one course of one or more other languages. This prior experience in L2 learning could explain why these students would be less anxious when faced with a now familiar learning process, while most learners of English are still learning their first language other than their mother tongue: Only 29\% of our English-learning participants reported having taken a course of another language. A second possibility is that, no matter the participants' bilingual status, it can be assumed that Québec students who decide to tackle a foreign language like Spanish are more selfconfident and take more risks than those who opt for English, an official language that is more easily accessible in everyday life. Risk-taking has long been considered a concept closely intertwined with anxiety $(\mathrm{H}$. Brown, 1973; Saito \& Samimy, 1996; Samimy $\&$ Tabuse, 1992). However, such a phenomenon may be not related to the language's status and presence in the learner's environment, but to familiarity with the languages and writing systems involved, where a new writing system and/or unfamiliar language could counterbalance the anxiety-reducing effects of prior language learning. Research on second and third languages of various official statuses and writing systems will help clear the picture. Another possibility is that despite the fact that English is more readily accessible in everyday life, learners' mental readiness may be counterbalanced by anxiety stemming from the limited success they had achieved: Despite many years of ESL courses, less than half of them (51/129; see Table 1) qualified for advanced levels, and of the only 29 students that qualified as advanced at their first university semester, 10 had taken English at cegep. This means that only $14.7 \%$ of our ESL learners (19/129) managed to reach an advanced level despite 8 years of English in the Québec school system, along with exposure to English through the media. A fourth explanation for our Spanish learners' lower anxiety could be attributed to 
cognateness: Spanish resembles French more than does English, especially with regard to pronunciation and syntax.

A second element of interest is the fact that in Table 3, the $p$ value for writing anxiety (.09) is much closer to the alpha level than for other types of anxiety, along with a $t$ value much higher than its counterparts. There is therefore a tendency for writing anxiety to be lower in distance learning than in classroom learning, and it makes sense because, traditionally, people who enroll in distance courses expect to write more, and students who are less anxious about writing are the ones who will be more willing to take such courses.

\section{Limitations}

As with most research, there are limitations related to the instruments used and the population tested in this study. Among those are recent claims by Lafontaine and De Serres (2007) concerning weaknesses in the validation of the FLRAS and the fact that some of its items would measure attitudes more than anxiety. These authors developed a new scale of measuring foreign language reading anxiety whose use in a study similar to this one could yield a different pattern of results. Likewise, the FLCAS has been criticized by Sparks and his colleagues (see Sparks \& Ganschow, 2007) on the grounds that, in addition to anxiety, many of the items on the FLCAS would involve students' attitudes and perceptions about language and about their own language learning skills. In addition, the use of multiple $t$ tests in this study raises the possibility that some of the significant findings are due to chance alone.

In the case of classroom learners, surprisingly, our study contradicts earlier research by indicating similar levels of anxiety between first-semester and more experienced language students in Québec. To further explore this element, comparisons are needed between students from school systems with various language learning requirements, in order to investigate the im- pact of the number of years of schooling on anxiety upon entering university.

\section{Teaching Implications}

Our study indicates no differences in anxiety profiles between classroom and distance learners in the case of French-speaking language learners in Québec universities, and it shows close to significant higher anxiety among first-semester students than among more experienced learners in the case of distance learning. This similarity in anxiety profiles between the two settings reflects the changing face of distance education. Distance learning, which could have been considered a safe haven for anxious language students in need of more motivational support, is now home to students whose socio-demographic and anxiety profiles resemble more and more those of traditional classroom students. In fact, the higher amounts of student anxiety that professors notice in distance learning as compared to classroom teaching could be due to the nature of distance learning. The relative anonymity inherent to distance learning, coupled with one-on-one contact between students and their tutor/professor, could make students less reluctant to express their anxiety than in classrooms surrounded by their peers. Consequently, even though the results of this study do not suggest higher anxiety among distance learners, professors and tutors in language education feel they need to address and alleviate students' anxiety more than in classroom situations. In addition to advocating individual contacts aimed at reassuring and motivating students, ${ }^{10}$ some anxiety-reducing strategies mentioned in this article lend themselves well to distance learning: using more extensive and detailed written material, using portfolios for assessment, providing more material for test preparation, and including interesting and humorous content.

\section{Future Research}

More research is warranted on the efficiency of the aforementioned anxiety-reducing 
methods in distance vs. classroom contexts. This study also observed two tendencies: a tendency for learners of Spanish to be less anxious than learners of English, and a tendency for writing anxiety to be lower in distance learning. Future research could help determine whether these tendencies are just statistical artifacts of our study or whether they are indicative of a real difference that would emerge with different, larger groups.

\section{Acknowledgments}

This work was supported by Téluq's Institutional Research Fund under Grant No. P350223. Partial results of this study were presented at the 2006 conference of the American Association of Applied Linguistics in Montréal, Québec. I also thank the anonymous reviewers for their helpful comments.

\section{Notes}

1. Some facilitative effects of anxiety have also been reported (K. Bailey, 1983; J. Brown, Robson, \& Rosenkjar, 2001; MacIntyre \& Gardner, 1994; Tobias, 1986), and it remains unclear whether anxiety or self-confidence influence performance and/or whether the latter impacts the former (see Matsuda \& Gobel, 2004; Sparks \& Ganschow, 2007).

2. Tutors are people in contact with students, hired as lecturers in distancelearning contexts where the professor's academic role revolves around course creation and tutor supervision.

3. For an overview of studies on these personality factors in distance education, see Thompson (1998) or Bourdages (1996).

4. The closest psychological component to anxiety that was considered in distance education is probably the students' initial level of confidence in their capacity to succeed, mentioned by Gibson (1991) as being strongly related to nonpersistence among beginners.
5. Téluq has recently become the distance learning component of the Universite du Québec à Montréal, after more than 30 years as an independent university devoted exclusively to distance education. It provides education to more than 20,000 distance students.

6. This being said, it does not imply that anxiety necessarily declines as students progress in the study of the language. For counterexamples, see Casado and Dereshiwsky (2001) and Machida (2001, in Matsuda \& Gobel, 2004).

7. Question 10: "By the time you get past the funny letters and symbols in English, it's hard to remember what you're reading about"; Question 11: "I am worried about all the new symbols you have to learn in order to read English"; Question 15: "The hardest part of learning English is learning to read"; Question 16: "I would be happy just to learn to speak English rather than having to learn to read as well."

8. Language courses are not taken every semester. For example, a student can take an L2 course during the third year of a program. Consequently, in this article, "semesters" refer to semesters when students take language courses.

9. In Québec, cegep (Centres d'enseignement général et professionnel) is an additional academic level consisting of two- and three-year programs between high school and university.

10. For a list of teaching behaviors and interventions suggested for reducing students' language anxiety, see Young, 1999b, pp. 242-243.

\section{References}

Abu-Rabia, S. (1999). Toward a second language model of learning in problematic social contexts. Race, Ethnicity and Education, 2, 109-125.

Abu-Rabia, S. (2004). Teacher's role, learner's gender differences, and FL anxiety among 
seventh-grade students studying English as a FL. Educational Psychology, 24(5), 711-721.

Aida, Y. (1994). Examination of Horwitz, Horwitz and Cope's construct of foreign language anxiety: The case of students of Japanese. Modern Language Journal, 78(2), 155-167.

Ariza, E. N. (2002). Resurrecting "Old" language learning methods to reduce anxiety for new language learners: Community language learning to the rescue. Bilingual Research Journal, 26(3), 717-728.

Bailey, K. M. (1983). Competitiveness and anxiety in adult second language learning: Looking at and through the diary studies. In H. W. Seliger \& M. H. Long (Eds.), Classroom oriented research in second language acquisition (pp. 67-102). Rowley, MA: Newbury House.

Bailey, P., Onwuegbuzie, A. J., \& Daley, C. E. (2000). Correlates of anxiety at three stages of the foreign language learning process. Journal of Language and Social Psychology, 19(4), 474-490.

Baker, S. C., \& MacIntyre, P. D. (2000). The role of gender and immersion language orientations. Language Learning, 50(2), 311-341.

Bancroft, W. J. (1976). Suggestology and suggestopedia: The theory of the Lozanov Method. Journal of Suggestive-Accelerative Learning \& Teaching, 1(3), 187-216.

Berk, R. A. (2000). Does humor in course tests reduce anxiety and improve performance? College Teaching, 48(4), 151-159.

Bourdages, L. (1996). La persistance et la nonpersistance aux études universitaires sur campus et en formation à distance. DistanceS, 1(1), 51-67.

Brown, H. D. (1973). Affective variables in second language acquisition. Language Learning, 23(2), 231-244.

Brown, J. D., Robson, G., \& Rosenkjar, P. R. (2001). Personality, motivation, anxiety, strategies and language proficiency of Japanese students. Motivation and Second Language Acquisition, 23, 361-398.

Burge, E. J., Howard, J. L., \& Ironside, D. J. (1991). Mediation in distance learning: An investigation of the role of tutoring. Toronto: OISE.

Casado, M. A., \& Dereshiwsky, M. I. (2001). Foreign language anxiety of university students. College Student Journal, 35(4), 539-550.

Casado, M. A., \& Dereshiwsky, M. I. (2004). Effect of educational strategies on anxiety in the second language classroom: An exploratory comparative study between U.S. and Spanish first-semester university students. College Student Journal, 38(1), 23-35.

Chen, T.-Y., \& Chang, G. B. Y. (2004). The relationship between foreign language anxiety and learning difficulties. Foreign Language Annals, 37, 279-290.

Cheng, Y., Horwitz, E. K., \& Schallert, D. L. (1999). Language anxiety: Differentiating writing and speaking components. Language Learning, 49, 417-446.

Crépuq (Conférence des recteurs et des principaux des universités du Québec). (2005). Données préliminaires relatives aux inscriptions au trimestre d'automne, Sous-comité des registraires, annuel. Retrieved August 30, 2006, from http://www.crepuq.qc.ca/article.php3? id_arti cle $=102=$ fr.

Curran, C. (1976). Counseling-learning in second languages. Apple River, IL: Apple River Press.

Daly, J. A., \& Miller, M. D. (1975). The empirical development of an instrument of writing apprehension. Research in the Teaching of English, 9, 242-249.

Davis, B. G. (1993). Tools for teaching. San Francisco: Jossey-Bass.

Dutton, J., Dutton, M., \& Perry, J. (2002). How do online students differ from lecture students? Journal of Asynchronous Learning Networks, 6(1) [Electronic version]. Retrieved January 15, 2007, from http://www.aln.org/ publications/jaln/v6n1/v6n1_dutton.asp.

Elkhafaifi, H. (2005). Listening comprehension and anxiety in the Arabic language classroom. Modern Language Journal, 89(2), 206220.

Ellis, R. (1994). The study of second language acquisition. Oxford, United Kingdom: Oxford University Press.

Frantzen, D., \& Magnan, S. S. (2005). Anxiety and the true beginner-false beginner dynamic in beginning French and Spanish classes. Foreign Language Annals, 38, 171-190.

Gagné, P., Bégin, J., Laferrière, L., Léveillé, P., \& Provencher, L. (2001). L'encadrement des études à distance par des personnes tutrices: Qu'en pensent les étudiants? DistanceS, 5(1), 59-83 [Electronic version]. Retrieved September 20, 2006, from http://cqfd.teluq.uquebec.ca/distances/D5_1_d.pdf.

Gardner, R. C. (1982). Language attitudes and language learning. In E. B. Ryan \& H. Giles 
(Eds.), Attitudes towards language variation (pp. 132-147). London: Arnold.

Gardner, R. C., \& MacIntyre, P. D. (1993). A student's contributions to second-language learning. Part II: Affective variables. Language Teaching, 26, 1-11.

Gardner, R. C., Smythe, P. C., \& Clément, R. (1979). Intensive second language study in a bicultural milieu: An investigation of attitudes, motivation and language proficiency. Language Learning, 29, 305-320.

Gardner, R. C., Tremblay, P. F., \& Masgoret, A. (1997). Towards a full model of second language learning: An empirical investigation. Modern Language Journal, 81, 344-362.

Gibson, C. C. (1991). In but for how long? Factors affecting persistence in the early months of distance learning. Paper presented at the 7th Annual Conference on Distance Teaching and Learning, Madison, University of Wisconsin, August.

Hamel, C. (2006). Writing and student anxiety: How to work with anxious students. Retrieved October 2, 2006, from http://www.salt.ari zona.edu/tutoringFiles/tutorHandouts/Writ ing\%20and\%20Student\%20Anxiety.pdf

Horwitz, E. K. (2001). Language anxiety and achievement. Annual Review of Applied Linguistics, 21, 112-126.

Horwitz, E. K., Horwitz, M. B., \& Cope, J. A. (1986). Foreign language classroom anxiety. Modern Language Journal, 70, 125-132.

Kim, J. H. (2000). Foreign language listening anxiety: A study of Korean students learning English. Unpublished thesis, University of Texas, Austin.

Koch, A. S., \& Terrell, T. D. (1991). Affective reactions of foreign language students to natural approach activities and teaching techniques. In E. K. Horwitz \& D. J. Young (Eds.), Language anxiety: From theory and research to classroom implications (pp. 109-126). Englewood Cliffs, NJ: Prentice Hall.

Krashen, S. (1982). Principles and practice in second language acquisition. Oxford, United Kingdom: Pergamon.

Krashen, S., \& Terrell, T. (1983). The Natural Approach: Language acquisition in the classroom. Oxford, United Kingdom: Pergamon.

Lafontaine, M., \& De Serres, L. (2007). Élaboration et validation d'échelles d'attitudes envers la lecture en français langue première, de motivation et d'anxiété envers la lecture en anglais langue seconde. Revue canadienne des sciences du comportement, 39, 92-109.

Liu, M. (2006). Anxiety in Chinese EFL students at different proficiency levels. System, 34(3), 301-316.

Lozanov, G. (1978). Suggestology and outlines of suggestopedia. New York: Gordon and Breach.

Lucas, J. (1984). Communication apprehension in the ESL classroom: Getting our students to talk. Foreign Language Annals, 17, 593-598.

Machida, S. (2001). Anxiety in Japanese-language class oral examinations. Sekai no Nihongo Kyoiku, 11, 115-138.

MacIntyre, P. D. (1995). How does anxiety affect second language learning? A reply to Sparks and Ganschow. Modern Language Journal, 79, 90-99.

MacIntyre, P. D., \& Gardner, R. C. (1991). Methods and results in the study of anxiety in language learning: A review of the literature. Language Learning, 41, 85-117.

MacIntyre, P. D., \& Gardner, R. C. (1994). The subtle effects of language anxiety on cognitive processing in the second language. Language Learning, 44, 283-305.

Matsuda, S., \& Gobel, P. (2004). Anxiety and predictors of performance in the foreign language classroom. System, 32, 21-26.

Phillips, E. (1992). The effects of language anxiety on students' oral test performance and attitudes. Modern Language Journal, 76, 14-26.

Pilon, G. (2006, May 21). Quatre fois mère et étudiante. Le Journal de Montréal, p. 9.

Price, M. L. (1991). The subjective experience of foreign language anxiety: Interviews with highly anxious students. In E. K. Horwitz \& D. J. Young (Eds.), Foreign language anxiety: From theory to research to classroom practices (pp. 101-108). Englewood Cliffs, NJ: Prentice Hall.

Qin, G. (2003). The influence of personality on foreign language learning. US-China foreign language, Vol. 1, October. Retrieved October 2, 2006, from http://www.linguist.org.cn/doc/ uc200310/20031013.doc.

Rodriguez, M., \& Abreu, O. (2003). The stability of general foreign language classroom 
anxiety across English and French. Modern Language Journal, 87, 365-374.

Saito, Y., Garza, T., \& Horwitz, E. (1999). Foreign language reading anxiety. Modern Language Journal, 83, 202-218.

Saito, Y., \& Samimy, K. K. (1996). Foreign language anxiety and language performance: A study of learner anxiety in beginning, intermediate, and advanced-level college students of Japanese. Foreign Language Annals, 29, 239-251.

Samimy, K. K., \& Tabuse, M. (1992). Affective variables and a less commonly taught language: A study in beginning Japanese classes. Language Learning, 42, 377-398.

Sparks, R. L., \& Ganschow, L. (2007). Is the Foreign Language Classroom Anxiety Scale measuring anxiety or language skills? Foreign Language Annals, 40(2), 260-287.

Tanaka, K., \& Ellis, R. (2003). Study abroad, language proficiency, and learner beliefs about language learning. JALT Journal, 25, 63-85.

Téluq (2004). Compendium Télé-Université 2003-2004. Téluq: Presses de l'Université du Québec.

Thompson, M. M. (1998). Distance learners in higher education. In C. C. Gibson (Ed.), Distance learners in higher education: Institutional responses for quality outcomes (pp. 1018). Madison, WI: Atwood Publishing.

Tobias, S. (1986). Anxiety and cognitive processing of instruction. In R. Schuwarzer (Ed.), Self-related cognition in anxiety and motivation (pp. 35-54). Hillsdale, NJ: Erlbaum.
VanPatten, B., \& Glass, W. R. (1999). Grammar learning as a source of language anxiety: A discussion. In D. J. Young (Ed.), Affect in foreign language and second language learning. A practical guide to creating a low-anxiety classroom atmosphere (pp. 89-105). Boston: McGraw-Hill.

Vogely, A. J. (1998). Listening comprehension anxiety: Students' reported sources and solutions. Foreign Language Annals, 31, 67-80.

Wiltse, E. M. (2000). The effects of motivation and anxiety on college students' use of instructor comments. Unpublished doctoral dissertation, The University of Wyoming, Laramie. Retrieved May 11, 2005, from http://uwadmnweb.uwyo. edu/COJO/WILTSE/dissertation.htm.

Woodrow, L. (2006a). A model of adaptive language learning. Modern Language Journal, 90, 297-319.

Woodrow, L. (2006b). Anxiety and speaking English as a second language. RELC, 37(3), 308-328.

Young, D. J. (1991). Creating a low-anxiety classroom environment: What does language anxiety research suggest? Modern Language Journal, 75, 426-439.

Young, D. J. (Ed.). (1999a). Affect in foreign language and second language learning: A practical guide to creating a low-anxiety classroom atmosphere. New York: McGraw-Hill.

Young, D. J. (1999b). Giving priority to the language learner first. In D. J. Young (Ed.), Affect in foreign language and second language learning. A practical guide to creating a low-anxiety classroom atmosphere (pp. 241-246). Boston: McGrawHill.

\section{APPENDIX A}

\section{Anxiety Scales Used}

Items preceded by an asterisk were not used in this study.

\section{FLCAS}

\section{Directions}

Statements 1 through 33 refer to how you feel about learning a foreign language (English). For each statement, please indicate whether you (1) strongly agree, (2) agree, (3) neither agree nor disagree, (4) disagree, or (5) strongly disagree by marking the appropriate number on the line following each statement. Please give your first reaction to each statement and mark an answer for every statement. 
1. I never feel quite sure of myself when I am speaking in English.

2. I don't worry about making mistakes in English class.

3. I tremble when I know that I'm going to be called on in English class.

4. It frightens me when I don't understand what the teacher is saying in English.

5. It wouldn't bother me at all to take more English classes.

6. During English class, I find myself thinking about things that have nothing to do with the course.

7. I keep thinking that the other students are better at English than I am.

8. I am usually at ease during tests in my English class.

9. I start to panic when I have to speak without preparation in English class.

10. I worry about the consequences of failing my English class.

11. I don't understand why some people get so upset over English class.

12. In English class, I can get so nervous I forget things I know.

13. It embarrasses me to volunteer answers in my English class.

14. I would not be nervous speaking English with native speakers.

15. I get upset when I don't understand what the English teacher is correcting in English.

16. Even if I am well prepared for English class, I feel anxious about it.

17. I often feel like not going to my English class.

18. I feel confident when I speak in my English class.

19. I am afraid that my English teacher is ready to correct every mistake I make.

20. I can feel my heart pounding when I am going to be called on in my English class.

21. The more I study for an English test, the more confused I get.

22. I don't feel pressure to prepare very well for English class.

23. I always feel that the other students speak English better than I do.

24. I feel very self-conscious about speaking English in front of other students.

25. English class moves so quickly I worry about getting left behind.

26. I feel more tense and nervous in my English class than in my other classes.

27. I get nervous and confused when I am speaking in my English class.

28. When I'm on my way to English class, I feel very sure and relaxed.

29. I get nervous when I don't understand every word the English teacher says.

30. I feel overwhelmed by the number of rules you have to learn to speak English.

31. I am afraid that the other students will laugh at me when I speak English.

32. I would probably feel comfortable around native speakers of English.

33. I get nervous when the English teacher asks questions which I haven't prepared in advance.

\section{FLRAS}

\section{Directions}

Statements 1 through 20 refer to how you feel about learning a foreign language (English). For each statement, please indicate whether you (1) strongly agree, (2) agree, (3) neither agree nor disagree, (4) disagree, or (5) strongly disagree by marking the appropriate number on the line following each statement. Please give your first reaction to each statement and mark an answer for every statement.

1. I get upset when I'm not sure whether I understand what I'm reading in English.

2. When reading English, I often understand the words but still can't understand what the author is saying.

3. When I'm reading English, I get so confused I can't remember what I'm reading.

4. I feel intimidated whenever I see a whole page of English in front of me. 
5. I am nervous when I am reading a passage in English when I am not familiar with the topic.

6. I get upset whenever I encounter unknown grammar when reading English.

7. When reading English, I get nervous and confused when I don't understand every word.

8. It bothers me to encounter words I can't pronounce while reading English.

9. I usually end up translating word by word when I'm reading English in front of me.

*10. By the time you get past the funny letters and symbols in English, it's hard to remember what you're reading about.

*11. I am worried about all the new symbols you have to learn in order to read English.

12. I enjoy reading English.

13. I feel confident when I am reading in English.

14. Once you get used to it, reading English is not so difficult.

* 15. The hardest part of learning English is learning to read.

*16. I would be happy just to learn to speak English rather than having to learn to read as well.

17. I don't mind reading to myself, but I feel very uncomfortable when I have to read English aloud.

18. I am satisfied with the level of reading ability in English that I have achieved so far.

19. English culture and ideas seem very foreign to me.

20. You have to know so much about English history and culture in order to read English.

* The asterisks identify the questions that were not used in the present study (cf. endnote $\# 7$ ).

Daly-Miller Writing Apprehension Test

\section{Directions}

Select the response from 1 to 5 that best suits your feelings about the following statements. Remember, there are no correct answers. Only give your honest response to each item.

$5=$ strongly disagree, $4=$ disagree, $3=$ uncertain, $2=$ agree, $1=$ strongly agree

1. I avoid writing in English.

2. I have no fear of my writing in English being evaluated.

3. I look forward to writing down my ideas in English.

4. I am afraid of writing essays in English when I know they will be evaluated.

5. Taking a composition course in English is a very frightening experience.

6. Handing in a composition in English makes me feel good.

7. My mind seems to go blank when I start to work on a composition in English.

8. Expressing ideas through writing in English seems to be a waste of time.

9. I would enjoy submitting my writing in English to magazines for evaluation and publication.

10. I like to write my ideas down in English.

11. I feel confident in my ability to clearly express my ideas when writing in English.

12. I like to have my friends read what I have written in English.

13. I'm nervous about writing in English.

14. People seem to enjoy what I write in English.

15. I enjoy writing in English.

16. I never seem to be able to clearly write down my ideas in English.

17. Writing in English is a lot of fun. 
18. I expect to do poorly in English composition classes even before I enter them.

19. I like seeing my thoughts on paper in English.

20. Discussing my writing in English with others is an enjoyable experience.

21. I have a terrible time organizing my ideas in a English composition course.

22. When I hand in a composition in English I know I'm going to do poorly.

23. It's easy for me to write good compositions in English.

24. I don't think I write as well in English as most other people.

25. I don't like my compositions in English to be evaluated.

26. I'm no good at writing in English.

\section{APPENDIX B}

Background Questionnaire (Version for learners of Spanish, translated from French)

Identification questionnaire for learners of Spanish

Name:

Email:

Sex: $\square \mathrm{M} \quad \square \mathrm{F}$

Age:

University: $\square$ University X (* courses) $\square$ University Y (*distance courses)

Mother tongue:

Current course level in Spanish:

Without considering English in elementary and high school, have you ever taken other second language courses? $\square$ No $\square$ Yes

If so:

What language(s)?

Where?

It was $\square$ In a classroom $\square$ A distance course

Is it your first language course at the university?

$\square$ Yes $\square$ No

If not, which one is it?

$\square$ my second

$\square$ my third

$\square$ my fourth or more 